\title{
MEDIASI LOKAL SEBAGAI MODEL UTAMA PENYELESAIAN KASUS PERCERAIAN MASYARAKAT MUSLIM KALISAT PASURUAN
}

\author{
Nor Salam \\ Sekolah Tinggi Agama Islam Al-Yasini Pasuruan, Indonesia \\ E-mail: salamsalembu@gmail.com
}

\begin{abstract}
This article analyzes the background of the legal pattern of the community at Kalisat Pasuruan in making local mediation as the main model to resolve divorce cases. This study uses a socio-legal approach with the Legal System Theory initiated by Lawrence Meir Friedman. This article is based on the emergence of the Supreme Court Regulation on Mediation in order to change the image of the Religious Courts from judicial paradigm to dispute resolution paradigm, including in divorce cases. The mediation in the case is imperative and the denial of mediation process in the court results in the cancellation of the decision by law. This study concludes that the alignment of the Kalisat community towards local mediation is much more due to non-legal factors which are categorized into elements of legal culture than to structural elements or legal substances. The legal culture element that is intended for example concerns the understanding of the Kalisat community on the teachings of their religion, their perceptions of the proceedings in the Religious Court in resolving divorce cases, or other factors such as the emotional closeness between them and community leaders who are local mediators.
\end{abstract}

Keywords: Divorce; local mediation; legal culture.

\section{Pendahuluan}

Perdebatan teoretis seputar keberlakuan hukum apakah secara positivistik atau secara sosiologis bukanlah perdebatan baru. Keduanya muncul dalam jagat kajian tentang ilmu hukum. Di satu sisi, regulasi hukum dipandang efektif manakala telah dirumuskan secara positivistik dalam bentuk perundang-undangan, namun di sisi yang berbeda, rumusan hukum yang tertuang dalam perundang-undangan membutuhkan justifikasi sosiologis dari masyarakat sebagai pengguna 
hukum tersebut. Karena itu, meminjam teori yang dikemukakan oleh Lawrence M. Friedman, hukum akan efektif manakala tiga elemen yang ada di dalamnya sama-sama memainkan peranannya, yaitu struktur hukum, substansi hukum, dan kultur hukum. ${ }^{1}$ Dalam narasi demikian ini, kajian terhadap mediasi lokal dalam kasus perceraian yang dijadikan model penyelesaiannya oleh masyarakat Kalisat menemukan relevansinya. Pola demikian dapat diletakkan sebagai konstruksi hukum yang tumbuh dalam kosmologi masyarakat Kalisat yang secara tidak langsung mengikis "arogansi" mediasi yudisial mazhab pengadilan.

Dalam kajian hukum secara empiris, hukum seringkali dinyatakan sebagai hasil konstruksi bersama yang terbentuk melalui interaksi antar individu maupun kelompok. Hasil konstruksi itu kemudian diinternalisasi ke dalam diri individu dan akhirnya dimasyarakatkan kepada lingkungan sekitarnya. Jika hasil konstruksi itu bermakna dalam kehidupan mereka, maka ia akan dilembagakan dan dilaksanakan dalam kehidupan sehari-hari. Namun jika ternyata hasil konstruksi itu tidak bermakna atau dengan kata lain tidak sesuai dengan kebutuhan masyarakat, maka akan terlihat adanya ragam penyimpangan di dalamnya. ${ }^{2}$ Demikian halnya dengan mediasi lokal, yang dalam hal ini peneliti maksudkan sebagai mediasi yang berlaku dan hidup dalam suatu komunitas tertentu tepatnya masyarakat desa Kalisat yang secara nyata diwujudkan dalam memandu kehidupan masyarakatnya. ${ }^{3}$ Mediasi tersebut tumbuh dari hasil konstruksi mereka yang disandarkan pada nilai-nilai luhur yang dipedomani seperti prinsip kerukunan, sehingga dalam hal penyelesaian suatu kasus yang timbul, termasuk kasus hukum keluarga yang terjadi dalam kehidupan

\footnotetext{
1 Susan S. Silbey, "Legal Culture and Cultures of Legality", dalam, John R. Hall, Laura Grindstaff and Ming Cheng Lo (eds.), Handbook of Cultural Sociology (New York: Routledge, 2010), 471; Lawrence M. Friedman, American Law in the 20th Century (United States of America: R. R. Donnelley \& Sons, 2002), 505.

2 Dominikus Rato, Hukum dalam Perspektif Konstruksi Sosial (Yogyakarta: LaksBang Mediatama, 2009), 12.

3 Definisi terhadap mediasi lokal yang digunakan dalam tulisan ini tentu dapat dibedakan dengan mediasi adat yang berlaku secara normatif dalam suatu masyarakat hukum adat. Dalam makna yang demikian ini, bisa saja pola mediasi yang terjadi di masyarakat Kalisat akan berbeda dengan pola mediasi di tempat yang berbeda. Pemaknaan demikian penulis sandarkan pada pembedaan antara hukum lokal dan hukum adat sebagaimana pernah dikaji oleh Dominikus Rato. Lihat, Dominikus Rato, Dunia Hukum Orang Osing (Yogyakarta: LaksBang Mediatama, 2009), 9.
} 
mereka selalu diupayakan melalui proses musyawarah, yakni proses pengambilan keputusan dengan saling berkonsultasi. ${ }^{4}$

Bagi masyarakat Kalisat, mediasi lokal yang ditempuhnya dinilai sebagai pengejawantahan dari semangat yang dikandung dalam alQur'ān surah al-Nisā' ayat 35 yang memerintahkan untuk mengutus hakamayn baik yang berasal dari kerabat dekat suami-istri maupun hakamayn di luar keluarga dekat ${ }^{5}$ mereka dengan tujuan mencari jalan keluar dari kasus yang sedang dihadapinya. Selain itu, dilakukannya mediasi lokal juga didasarkan pada hadīth nabi yang menyatakan bahwa perceraian adalah perkara mubah yang sangat dibenci oleh Allah. ${ }^{6}$ Atas dasar inilah, maka perceraian dalam pandangan tokoh masyarakat Kalisat yang menjadi mediator-mediator lokal, harus dicegah selama masih memungkinkan untuk didamaikan kembali atau setidaknya dapat mewujudkan perceraian yang diistilah oleh Constance Ahrons sebagai the good divorce. ${ }^{7}$

Hadirnya peraturan Mahkamah Agung tentang mediasi menjadi titik awal "pembredelan" terhadap eksistensi mediasi lokal yang nyatanyata lahir sebagai sebuah kesepakatan komunitas dalam menyelesaikan kasus perceraian yang terjadi dalam kehidupan mereka. Di bawah optik kuasa pengadilan, dirumuskanlah sebuah istilah court connected mediation yang mengintegrasikan antara proses beracara di

\footnotetext{
${ }^{4}$ Franz Magnis-Suseno, Etika Jawa: Sebuah Analisa Falsafi tentang Kebijaksanaan Hidup Jawa (Jakarta: PT. Gramedia, 1985), 51.

${ }^{5}$ Menurut Wahbah al-Zuhaylī, mengutus ḥakam dari keluarga dekat merupakan hal yang dianjurkan dan bukan bersifat wajib. Wahbah al-Zuhaylī, al-Tafsì al-Munir fì al'Aqidah wa al-Shari' ah wa al-Minhaj, Vol. 3 (Damaskus: Dār al-Fikr, 2009), 62.

${ }^{6}$ Melalui penelusuran terhadap karya A. J. Wensick, al-Mújam al-Mufahras li AlfäzalHadith al-Nabawi, terdapat dua redaksi hadīth yang menunjukkan pada pemaknaan tersebut, yakni redaksi abghad al-ḥaläl ilā Allah al-talāq dan redaksi mà aḥalla Allah shay'an abghad ilayh min al-taläq. A. J. Wensick, al-Mu'jam al-Mufahras li Alfäz al-Hadith al-Nabawi, Vol. 4 (Leiden: Maktabah Brill, 1926), 25; lihat juga Ibid., Vol. 1, 202. Menurut al-Juwaynī, dari hadīth tersebut nyatalah bahwa talak yang dihukumi makruh adalah talak yang terjadi tanpa didasari adanya alasan yang dapat dibenarkan. 'Abd al-Mālik b. 'Abd Allāh b. Yūsuf al-Juwaynī, Nihāyat al-Matlab fì Dirāyat al-Madhhab, Vol. 14 (Jeddah: Dār al-Minhāj, 2007), 11.

7 The good divorce yang dimaksudkan oleh Ahrons adalah situasi perceraian di mana hubungan antara anak dan kedua orang tua yang telah bercerai masih dapat berhubungan secara intim seperti sebelum terjadinya perceraian. Mereka tetap bertanggung jawab terhadap perkembangan emosional anak, kebutuhan ekonomi dan kebutuhan fisik yang lainnya. Constance Ahrons, The Good Divorce: Keeping Your Family Together When Your Marriage Comes Apart (t.t.: International and Pan-American, 2008), 2.
} 
pengadilan dengan proses mediasi namun berimplikasi pada pengabaian terhadap hasil apapun dari proses mediasi yang tidak dilakukan di bawah kendali pengadilan, termasuk mediasi yang tidak lakukan oleh seorang mediator bersertifikat. ${ }^{8}$ Tentu saja termasuk dalam kategori ini adalah mediasi lokal yang sejatinya dilakukan secara informal di luar proses peradilan.

Kuasa pengadilan-dengan optik postivistiknya dalam mengambil alih proses mediasi ke dalam nuansa yang menjamin kepastian hukum termasuk dalam kasus perceraian-bertumpu pada upaya mengubah paradigma yang selama ini melekat dalam masyarakat, yaitu sebagai institusi yang fokus untuk mengadili ke dalam paradigma yang menyelesaikan sengketa yang berporos pada asas kekeluargaan. Upaya perubahan paradigma itu dapat ditelusuri dari "jatuh bangunnya" sekian banyak instrumen hukum yang diarahkan sebagai bentuk penguatan terhadap lembaga mediasi. Semula didasarkan pada pasal 130 HIR ayat (1) dan ayat (2) serta pasal 154 RBG. ${ }^{9}$ Kemudian disusul dengan pemberlakuan Surat Edaran Mahkamah Agung (SEMA) Nomor 1 Tahun 2002 tentang Pemberdayaan Pengadilan Tingkat Pertama Menerapkan Lembaga Damai. Dilanjutkan dengan PERMA Nomor 2 Tahun 2003 ini, mediasi menjadi bagian dari proses beracara di pengadilan. ${ }^{10}$ Menyadari kelemahan dari PERMA Nomor 2 Tahun 2003, Mahkamah Agung kemudian melakukan penyempurnaan dengan mengeluarkan PERMA Nomor 1 Tahun 2008 tentang Prosedur Mediasi di Pengadilan, kemudian digantikan dengan

8 Misalnya saja, pasal 13 ayat (1) Peraturan Mahkamah Agung tentang Mediasi menyatakan "setiap mediator wajib memiliki sertifikat mediator yang diperoleh setelah mengikuti dan dinyatakan lulus dalam pelatihan sertifikasi mediator yang diselenggarakan oleh Mahkamah Agung atau lembaga yang telah memperoleh akreditasi dari Mahmakah Agung. Peraturan Mahkamah Agung Republik Indonesia Nomor 1 Tahun 2016 tentang Prosedur Mediasi di Pengadilan, pasal 13 ayat (1).

${ }_{9}^{9}$ Adapun bunyi dari pasal tersebut adalah "jika pada hari yang ditentukan itu kedua belah pihak datang, maka Pengadilan Negeri dengan pertolongan ketua mencoba akan memperdamaikan mereka; jika perdamaian yang demikian itu dapat dicapai, maka pada waktu bersidang diperbuat sebuah surat (akta) tentang itu, dalam mana kedua belah pihak dihukum akan menaati perjanjian yang diperbuat itu, surat mana akan berkekuatan dan akan dijalankan sebagai putusan yang biasa". R. Soesilo, RIB/HIR dengan Penjelasan (Bogor: Politeia, 1985), 88.

10 Syahrizal Abbas, Mediasi dalam Hukum Syariah, Hukum Adat dan Hukum Nasional (Jakarta: Kencana, 2011), 306; Retnowulan Sutantio, Mediasi dan Dading dalam Mediasi dan Perdamaian (Bandung: Alumni, t.th.), 22. 
PERMA Nomor 1 Tahun 2016 tentang prosedur mediasi di pengadilan. ${ }^{11}$

Dengan dijadikannya mediasi sebagai salah satu tahapan penting dalam proses berperkara, menunjukkan adanya upaya mengubah citra peradilan dari paradigma mengadili ke paradigma menyelesaikan sengketa hukum. ${ }^{12}$ Namun demikian, bagi masyarakat Kalisat, datangnya ke pengadilan dalam kasus hukum keluarga yang diajukannya bukan dalam rangka menempuh jalur perdamaian (mediasi) melainkan untuk mendapatkan legalitas atas tindakan hukum yang dilakukan. Dengan kata lain, perubahan paradigma pengadilan tidaklah berdampak pada penerimaan masyarakat Kalisat sebagai tempat yang tepat di dalam menyelesaikan kasus perceraian.

Kajian terhadap mediasi (lokal) dalam kasus hukum keluarga secara umum sebenarnya telah banyak dilakukan, tetapi dengan fokus dan kesimpulan yang berbeda dari apa yang penulis kaji dalam artikel ini. Salah satunya adalah kajian Jamāl Hashash,, ${ }^{13}$ Sa'odah Binti Ahmad, ${ }^{14}$ dan lain sebagainya.

Atas dasar kenyataan ini, maka dapat dipastikan bahwa kajian terhadap latar belakang menguatnya mediasi lokal vis a vis mediasi yudisial belum pernah dikaji, sehingga penting untuk dijawab seputar latar belakang menguatnya pandangan tersebut. Benarkah persoalan ini semata-mata dilatari hadirnya hukum negara dalam ruang sosial yang dinilai menjadi beban bagi penerimanya, ${ }^{16}$ atau justru kehadiran hukum negara tidak selamanya menimbulkan beban budaya selama skema berpikir anggota masyarakatnya memiliki kemampuan untuk mengakomodir nilai dan norma dalam kosmologi mereka. ${ }^{17}$ Artikel ini berupaya untuk menemukan latar belakang pola berhukum-dalam kajian sosiologi hukum disebut sebagai faktor-faktor non-hukum-

\footnotetext{
${ }^{11}$ Maskur Hidayat, Strategi dan Taktik Mediasi Berdasarkan PERMA No. 1 Tabun 2016 Tentang Prosedur Mediasi di Pengadilan (Jakarta: Kencana, 2016), 47.

12 Bagir Manan, Sistem Peradilan Berwibawa (Yogyakarta: UII Press, 2005), 25.

13 Ibid., 13.

14 Sa'odah Binti Ahmad, "Șulh: an Alternative Dispute Resolution and Amicable Settlement of Family Dispute", UMRAN: Journal of Muslim Affairs, Vol. 1, No. 1 (2015), 16. Sa'odah binti Ahmad dan Nora Abdul Hak, "Family Mediation and Sulh: an Alternative Dispute Resolution in Malaysia", International Journal of Social Policy and Society, Vol. 7 (2010), 16.

16 Bernard L. Tanya, Hukum dalam Ruang Sosial (Yogyakarta: Genta Publishing, 2010), 1.

${ }^{17}$ Rato, Dunia Hukum, 6.
} 
masyarakat Muslim Kalisat dalam menjadikan mediasi lokal sebagai model utama dalam menyelesaikan kasus perceraian.

\section{Potret Geografis dan Relasi Sosial Masyarakat Kalisat Pasuruan}

Merujuk pada definisi desa yang lazimnya dinyatakan sebagai wilayah hukum yang sekaligus menjadi pusat pemerintah tingkat daerah paling rendah dan secara administratif berada di bawah kekuasaan pemerintah kecamatan, ${ }^{18}$ maka Kalisat-sebagai lokus kajian dalam penelitian ini-adalah wilayah hukum terkecil yang berada di bawah kekuasaan pemerintah kecamatan Rembang. Sedangkan Rembang sendiri merupakan salah satu kecamatan yang berada di wilayah administrasi pemerintah kabupaten Pasuruan.

Kalisat yang tidak lain adalah pusat pemerintahan tingkat daerah paling bawah dalam cakupan administrasi pemerintah kecamatan Rembang terletak pada titik kordinat $7^{\circ} 40$ '34'S $112^{\circ} 47^{\prime} 9^{\prime \prime} E$. Desa ini merupakan salah satu desa yang posisinya agak terpencil dan lumayan jauh dari kota, tepatnya 15 kilometer arah ke barat (ke arah Bangil) dari kota Pasuruan dan berbatasan langsung dengan desa Oro Bulu di sebelah utara, sebelah timur berbatasan dengan desa Tampung dan sebelah barat berbatasan dengan desa Kedung Banteng yang semuanya termasuk wilayah hukum kecamatan Rembang. Adapun batas sebelah selatan, Kalisat berbatasan langsung dengan desa Candirobo yang termasuk salah satu desa dalam wilayah pemerintahan kecamatan Sukorejo. ${ }^{19}$

Kalisat dengan luas wilayah sekitar 392 hektar yang digunakan sebagai lahan sawah seluas 304,60 hektar, tegalan tanah kering pertanian seluas 6,50 hektar, bangunan dan pekarangan seluas 76,60 hektar, serta digunakan untuk tanah makam dan lainnya seluas 4,30 hektar, ${ }^{20}$ secara geologis berupa dataran rendah dengan suhu rata-rata $30^{\circ}$ C dan ketinggian tanah 58 meter di atas permukaan laut. Sedangkan ditinjau secara klimatologis, Kalisat merupakan daerah iklim tropis yang memiliki tingkat curah hujan sedang. ${ }^{21}$

\footnotetext{
${ }^{18}$ Kodiran, "Kebudayaan Jawa", dalam, Koentjaraningrat, Manusia dan Kebudayaan di Indonesia (t.t.: Penerbit Djambatan, 1980), 324.

${ }^{19}$ Dokumentasi, 16 Agustus 2017.

20 Aulia Fitriany dan Izzatul Fajriyah, "Sejarah Budaya Kawin Sirri di Desa Kalisat Kecamatan Rembang Kabupaten Pasuruan”, Jurnal Edukasi, Vol. 1 No. 2 (2015, 260.

${ }^{21}$ Dokumentasi, 16 Agustus 2017.
} 
Dari sisi penamaan, pada awalnya, desa Kalisat bernama Sumber Rejo. Penamaan Sumber Rejo didasarkan pada keberadaan sumber air yang sangat bersih dan besar di desa Kalisat. Dari sumber air inilah masyarakat mendapatkan kemudahan untuk mengairi lahan pertaniannya. Sementara penemu sumber air tersebut adalah mbah Putih yang akrab dengan panggilan Bioteh. Mbah Putih adalah seorang ulama besar yang disegani oleh masyarakatnya. Beliau tinggal di bawah pohon beringin tepat di samping keberadaan sumber air yang ditemukannya. ${ }^{22}$

Sedangkan penamaan Kalisat terhadap desa yang semula bernama Sumber Rejo ini, berdasarkan hasil dokumentasi penulis terhadap arsip desa Kalisat, ${ }^{23}$ diawali oleh sebuah peristiwa bersejarah tepatnya pada awal abad 16 semasa penjajahan Belanda. Pada saat itu terjadi pertempuran yang sengit antara pasukan Belanda dengan para gerilyawan. Kekuatan pasukan Belanda yang begitu kuat telah mendesak para gerilyawan pribumi mundur dari medan pertempuran hingga pada akhirnya para gerilyawan terkepung oleh pasukan Belanda. Pada saat para gerilyawan itu terkepung karena serangan pihak penjajah Belanda yang membabi buta, justru pada saat itu pula tentara mengentikan serangannya sehingga membuat para gerilyawan terheran-heran, dan kemudian mereka sadar akan kekuasaan Allah untuk melindungi (Kalisat) para gerilyawan dari kekejaman tentara Belanda. Pada saat itu pula, para gerilyawan dan penduduk setempat melakukan sujud syukur di tempat yang sekarang populer dengan nama desa Kalisat.

Sebagaimana umumnya kehidupan masyarakat desa yang diikat oleh sistem kekeluargaan, begitu pula halnya dengan kehidupan masyarakat Kalisat. Pola demikian itu dinyatakan oleh Ferdinand Tonnies sebagai masyarakat dengan pola gemeinschaft, yakni kehidupan bersama di mana anggota-anggotanya diikat dalam hubungan batin yang bersifat alamiah dan bersifat kekal, atau dengan kata lain, gemeinschaft adalah bentuk hidup bersama di mana para anggotanya dipersatukan dan disemangati dalam perilaku sosial oleh ikatan persaudaraan, simpati dan perasaan lainnya sehingga mereka terlibat secara psikis dalam suka duka hidup bersama. ${ }^{30}$

\footnotetext{
22 Aulia Fitriany, "Sejarah Budaya", 260.

${ }^{23}$ Dokumentasi, 16 Agustus 2017.

${ }^{30}$ Dewi Wulansari, Sosiologi Konsep dan Teori (Bandung: Refika Aditama, 2009), 62.
} 
Dalam kenyataan demikian ini, tidak mengherankan jika kemudian dalam kehidupan masyarakat Kalisat, kiai ditempatkan sebagai elit utama yang dijadikan tempat untuk mengadukan berbagai persoalan-sebagaimana umumnya dalam kehidupan masyarakat Madura ${ }^{31}$ - bahkan menurut Mahfudz, timbul rasa kurang meyakinkan jika persoalannya tidak diselesaikan terlebih dahulu oleh kiai termasuk dalam urusan akad nikah. Sebelum secara resmi dicatatkan di Kantor Urusan Agama, pasangan calon suami-istri terlebih dahulu meminta untuk diakadkan oleh seorang kiai. ${ }^{32}$

Kedudukan istimewa yang diberikan oleh masyarakat Muslim Kalisat terhadap elit utama yang disebutkan di atas, disebabkan oleh keikhlasan para tokoh masyarakat itu dalam memberikan pencerahan terhadap segala problem kehidupan masyarakat Kalisat yang diadukan kepada mereka. Menurut Abdul Qohir, semakin pudar keikhlasan tokoh masyarakat dalam memberikan bimbingan kepada masyarakat, maka semakin pudar pula kedekatan emosional yang terjalin. ${ }^{33}$

Keikhlasan seorang kiai dalam membimbing dan memberikan pencerahan kepada masyarakat Kalisat akan dibalas dengan sikap patuh, tunduk, dan mengabdi kepada kiai dengan berpegang pada prinsip manut kiai. Dalam narasi demikian ini, maka hubungan antara kiai dan anggota masyarakatnya ini melahirkan pola hubungan yang disebut dengan paternalisme, di mana hubungan antara pemimpin dan yang dipimpin, dalam konteks kajian ini adalah antara kiai dan anggota masyarakatnya, seperti hubungan antara ayah dan anak. ${ }^{34}$

Ketundukan dan sikap pasrah kepada seorang kiai yang terjadi di desa Kalisat, di samping sekian banyak faktor yang juga tidak dapat dipungkiri, menjadi faktor pendukung terjadinya praktik perkawinan

\footnotetext{
31 Menurut Kuntowijoyo, dalam kehidupan sosial masyarakat madura, terdapat tiga kelompok elit utama yang ditokohkan, yaitu santri, kiai dan haji. Santri adalah para murid yang menuntut ilmu agama, sementara kiai adalah guru-guru agama yang disebut guru ngaji jika mereka mengajarkan membaca al-Qur'ān, disebut guru ngaji kitab jika yang diajarkan adalah berbagai jenis buku. Di luar dua kelompok guru agama tersebut, Kuntowijoyo menyebutkan satu lagi guru agama yang disebut dengan guru tarekat atau pemimpin tarekat. Elit lain yang juga memiliki posisi terhormat adalah haji, yakni sebutan umum bagi seseorang yang telah menunaikan ibadah haji ke Mekkah. Lihat Kuntowijoyo, Perubahan Sosial dalam Masyarakat Agraris Madura 1850-1940 (Yogyakarta: Mata Bangsa, 2002), 328.

32 Mahfudz (Mediator Lokal), Wawancara, Kalisat 16 Oktober 2017.

33 Abdul Qohir (Media Lokal), Wawancara, Kalisat 08 November 2017.

${ }^{34}$ Mohammad Kosim, "Kiai dan Blater (Elite Lokal dalam Masyarakat Madura), KARSA, Vol. XII No. 2 (2007), 162.
} 
yang dinilai dari sudut pandang hukum negara sebagai perkawinan illegal. Katakanlah seperti praktik nikah siri yang terjadi di Kalisat. Pernikahan ini jelas mengandalkan kepercayaan akan keabsahan pernikahan yang hanya diakad oleh seorang kiai. Bahkan diibaratkan dengan orang yang sedang membeli tanah namun masih menunggu proses sertifikasi. ${ }^{35}$

\section{Latar Penyelesaian Kasus Peceraian Melalui Mediasi Lokal}

Dalam kajian sosiologi hukum, uraian terhadap faktor lahirnya pola berhukum suatu masyarakat menjadi penting karena memang "obsesi" sosiologi hukum adalah menggambarkan realitas hukum (law in action) sehingga pengamatan secara sistematis terhadap bekerjanya faktor-faktor non-hukum menjadi sebuah keniscayaan. ${ }^{36}$ Mengikuti alur berpikir demikian, maka ditemukan sekian banyak faktor yang melatari keberlakuan mediasi lokal dalam kasus perceraian di desa Kalisat, antara lain adalah faktor yang berupa pemahaman masyarakat Kalisat terhadap ajaran agama.

Melembaganya mediasi lokal sebagai alternatif penyelesaian kasus perceraian mendapatkan legitimasi dari pemahaman masyarakat Kalisat terhadap ajaran agama. ${ }^{37}$ Khusus dalam masalah perceraian, masyarakat Kalisat berpegang pada ketentuan dalam kitab-kitab fiqh yang dipahami sebagai dokumen ajaran agama Islam, di mana dalam kitab-kitab tersebut, dijelaskan bahwa terjadinya perceraian adalah hak mutlak seorang suami. Dengan kata lain, sekali diucapkan kata talak oleh seorang suami, apakah itu secara sarī ataupun kināyah, maka dianggap telah terjadi talak dan tidak membutuhkan persaksian. ${ }^{38}$ Aturan demikian berbeda dengan regulasi tentang perkawinan yang

\footnotetext{
35 "Masih Perawan Rp. 35 Juta Janda Rp. 15 Juta" dalam https://megapolitan .kompas.com / read/2010/02/20/14444468/diakses pada tanggal 12 Juni 2016.

36 Satjipto Rahardjo, Pemanfaatan Ilmu-ilmu Sosial bagi Pengembangan Ilmu Hukum (Yogyakarta: Genta Publishing, 2010), 15.

${ }^{37}$ Dalam kajian yang dilakukan oleh Ali Sodiqin, dengan menggunakan antropologi hukum sebagai pendekatan dalam penelitian hukum Islam, dinyatakan bahwa keberlakuan hukum dalam masyarakat ditentukan oleh pemahaman terhadap agama. Di samping faktor lain seperti hukum agama maupun hukum adat yang bersumber dari kepercayaan lokal. Ali Sodiqin, "Antropologi Hukum sebagai Pendekatan dalam Penelitian Hukum Islam”, al-Manāhij: Jurnal Kajian Hukum Islam, Vol. 7, No. 1 (2013), 123.

38 Menurut Sayyid Sābiq, ketentuan tersebut merupakan kesepakatan para ulama, karena talak merupakan hak prerogatif seorang suami. Sayyid Sabiq, Fiqh al-Sunnah, Vol. 2 (Kairo: Dār al-Fatḥ li al-I'lām al-'Arabī, 1995), 290.
} 
justru menyatakan secara tegas bahwa perceraian hanya dapat dilakukan di depan sidang pengadilan setelah pengadilan yang bersangkutan berusaha dan tidak berhasil mendamaikan kedua belah pihak. ${ }^{39}$

Menguatkan ketentuan fiqh tentang jatuhnya talak yang menjadi hak mutlak seorang suami, Abdul Qohir menyatakan, dalam ranah jatuh dan tidaknya perceraian, pengadilan tidak punya hak. Karena talak itu adalah hak seorang suami. Bahkan sekalipun pengadilan menyatakan talak seribu kali tetapi suami tidak menyatakannya maka tidak terjadi talak, begitu sebaliknya, sekalipun pengadilan menyatakan tidak terjadi talak, tetapi ketika sang suami telah mengucapkannya, maka tetap terjadi talak. Di sinilah lemahnya hukum di Indonesia menurut Qohir, karena di satu sisi disebut sebagai hukum yang shar ${ }^{6}$ namun di sisi lain, ia justru bertentangan dengan hukum sharì. Contoh yang diajukan Qohir adalah persoalan perceraian dan kawin siri. Perceraian yang oleh agama dinyatakan sah jika telah dilafalkan oleh seorang suami, oleh pengadilan dinyatakan tidak sah selama ia tidak diucapkan di dalam persidangan, sementara nikah siri yang oleh agama dibenarkan, menurut Qohir, ia dilarang oleh hukum di Indonesia. ${ }^{40}$

Selain faktor pemahaman agama, keberpihakan masyarakat Kalisat terhadap mediasi lokal juga disebabkan oleh faktor sosialisasi hukum. Pertanyaan mengapa kemudian seorang tokoh di pedesaan menjadi rujukan warga masyarakat, utamanya dalam kasus hukum keluarga dibandingkan dengan para aparatur negara. Menurut Husein, karena adanya penyampaian-penyampaian yang terkait dengan hukum, sehingga dari penyampaian para kiai itu, masyarakat lebih mudah memahami seputar hukum keluarga. Bahkan menurut Husein, persoalan seputar hukum-hukum perkawinan menjadi materi wajib dalam setiap kegiatan keagamaan yang berlangsung di desa Kalisat. Berbeda halnya-menurut Husein-dengan undang-undang atau apalah namanya yang dikeluarkan oleh pemerintah. Ia hanya menjadi perbincangan di kalangan orang-orang terdidik dan tidak pernah bisa dipahami oleh kalangan masyarakat awam seperti di desa Kalisat. Karena itu, menurut Husein, faktor utama yang menjadikan ketaatan masyarakat desa Kalisat kepada seorang tokoh, termasuk seorang kiai, adalah disebabkan oleh adanya pemahaman terhadap hukum-hukum

${ }^{39}$ Lihat, pasal 39 ayat (1) UU No. 1 Tahun 1974 dan pasal 115 Kompilasi Hukum Islam (KHI).

40 Abdul Qohir (Mediator Lokal), Wawancara, Kalisat 08 November 2017. 
yang seringkali disampaikan oleh para tokoh masyarakat setempat itu sendiri. Sementara apa yang disampaikan oleh para kiai itu, merupakan kebutuhan dari masyarakat setempat, sehingga dari situ timbul rasa untuk mengikuti apa yang disampaikan oleh para kiai. ${ }^{41}$

Dalam proses penyampaian hukum dalam kehidupan masyarakat Kalisat, Ismail menyatakan bahwa dirinya termasuk orang yang terlibat dalam proses penyampaian hukum yang dimaksudkan dari satu pengajian ke pengajian yang lain, dengan materi pokok seperti kitab Safinat al-Najăḥ yang di dalamnya banyak mengatur tentang persoalan 'ubüdiyyah. Selain kitab Safinat al-Najäh, menurut Ismail, materi pokok yang sering disampaikan adalah kitab Fath al-Qarib yang dikhususkan pada bab-bab terakhir yang mengatur tentang mu'ämalah seperti jual beli, sewa menyewa cara menggadaikan dan lain sebagainya. Itu semua menurut Ismail adalah pengajian di luar kegiatan pembelajaran di Madrasah, seperti melalui majelis-majelis manāqib ataupun jam'iyah salawwat. Adapun materi pokok yang disampaikan dalam pembelajaran di Madrasah yang Ismail pimpin adalah kitab 'Uqüd al-Lujayn dan Qurrat al-'Uyün.42

Faktor yang telah disebutkan di atas, dalam kajian sosiologi hukum diistilahkan sebagai proses sosialisasi hukum, yang dengan adanya sosialisasi itu diharapkan adanya motivasi dan sikap yang sesuai dari anggota masyarakat yang sedang diaturnya. 43 Dari sinilah dapat dipahami munculnya mediasi lokal melalui tokoh masyarakat sebagai mediatornya seperti yang terjadi di Kalisat tidak dapat dilepaskan dari faktor sosialisasi hukum yang intens oleh para kiai melalui majelis-majelis taklim yang diselenggarakannya. Sosialiasi hukum inilah yang kemudian melahirkan pengetahuan hukum (knowledge of the law) yang pada akhirnya berpengaruh terhadap perilaku hukum masyarakat (legal behavior). ${ }^{44}$

Begitu pula dengan faktor lain yang turut menjadi latar belakang keberlakuan mediasi lokal seperti adanya kesan di masyarakat akan Rumitnya Proses Mediasi di Pengadilan. Adanya ketentuan proses berperkara di pengadilan—dalam hal ini adalah Pengadilan Agama-

\footnotetext{
${ }^{41}$ Husein (Mediator Lokal), Wawancara, Kalisat 10 Agustus 2017.

${ }^{42}$ Ismail (Mediator Lokal), Wawancara, Kalisat 16 September 2017.

43 Roger Cotterrel, Sosiologi Hukum, terj. Narulita Yusron (Bandung: Nusa Media, 2016), 197.

${ }^{44}$ Achmad Ali, Menguak Teori Hukum dan Teori Peradilan, Vol. 1 (Jakarta: Kencana, 2013), 163.
} 
sebenarnya tidak hanya terbatas pada persoalan perceraian, melainkan semua perkara yang diajukan ke Pengadilan Agama harus mengikuti ketentuan yang telah diatur dalam hukum acara perdata 45 yang berlaku di lingkungan Peradilan Agama, salah satunya adalah kewajiban tentang proses perdamaian (mediasi). ${ }^{46}$ Adanya ketentuan berperkara yang diatur melalui hukum acara ini tujuannya adalah agar para pihak dapat melakukan hak dan kewajibannya secara seimbang di depan sidang pengadilan sesuai dengan ketentuan hukum yang berlaku. Karena itu pula, hukum acara disebut sebagai hukum formil karena ia mengatur tentang proses penyelesaian perkara melalui pengadilan sesuai dengan norma yang ditentukan secara formal. ${ }^{47}$ Tidak demikian halnya dengan apa yang dirasakan oleh masyarakat Kalisat terkait dengan aneka aturan yang menjadi ketentuan dalam proses peradilan. Ketentuan-ketentuan tersebut dirasakan sebagai proses berperkara yang berbelit-belit. ${ }^{48}$

Kerumitan proses berperkara di pengadilan merupakan satu dari sekian banyak hal yang dinilai sebagai proses litigasi yang tidak efisien. Dalam hal ini, dikatakan oleh Ahmad Ali dan Wiwie Heryani dalam buku Sosiologi Hukum: Kajian Empiris Terhadap Pengadilan, semakin cepat mengajukan perkaranya ke pengadilan, maka seorang pencari keadilan akan cepat pula menemukan ketidakefisienan selama berada di pengadilan, baik karena biaya hukum yang tinggi, waktu penyelesaian perkara yang relatif lama, maupun karena sebab lain berupa perasaan

\footnotetext{
${ }^{45}$ Hukum acara perdata yang dimaksudkan di sini merupakan ketentuan hukum yang mengatur tata cara mengajukan gugatan kepada pengadilan, upaya tergugat dalam membela diri atas gugatan yang ditujukan kepadanya, cara hakim bertindak dan memutuskan perkara serta cara melaksanakan hukum yang telah diputuskan. Lihat Abdul Manan, Penerapan Hukum Acara Perdata di Lingkungan Peradilan Agama (Jakarta: Kencana, 2016), 2.

46 Ketentuan ini diatur dalam pasal 82 Undang-Undang No. 7 Tahun 1989 jo. Undang-Undang No. 3 Tahun 2006 jo. Undang-Undang No. 50 Tahun 2009 tentang Peradilan Agama. Dalam ketentuan tersebut secara tegas dinyatakan-khususnya terkait dengan perkara perceaian-pada sidang pertama pemeriksaan gugatan perceraian, hakim berusaha untuk mendamaikan kedua pihak (ayat 1). Dalam proses perdamaian yang dimaksud, suami istri harus datang secara pribadi kecuali apabila salah satu pihak bertempat kediaman di luar negeri, dan tidak dapat datang menghadap secara pribadi dapat diwakili oleh kuasanya yang secara khusus dikuasakan untuk itu (ayat 2).

${ }^{47}$ Manan, Penerapan Hukum, 2.

${ }^{48}$ Durroh (Penggugat), Wawancara, Kalisat 10 November 2017.
} 
frustrasi menghadapi berbagai istilah hukum yang tidak mudah dipahami. ${ }^{49}$

Setidaknya, "kegalauan" yang digambarkan oleh Achmad Ali dan Wiwie Heryani ini dirasakan oleh Alfiyah. Dia mengakui adanya rasa gugup pada saat pertama kali memasuki ruang mediasi, yang kemudian ia ditanyakan seputar alasan yang menjadi penyebab perceraiannya hingga ia diberikan nasihat oleh mediator untuk membatalkan niatnya untuk bercerai. Menurut Alfiyah, mon mediasi ye awal seh rodok dredeg, tapi yo kedua wes biasa, e mediasi yo mik etanyaagi masalah awal apah teros mik iso teros akherrah harus bawa saksi (kalau mediasi, ya awalnya agaknya gugup tapi yang kedua ya sudah biasa. Dimediasi ya cuma ditanyakan apa masalah awal yang menjadi sebab perceraiannya kemudian ditanyakan kenapa harus bercerai dan akhirnya harus membawa saksi). 50

Begitu pula faktor lain yang berupa persepsi masyarakat kalisat tentang peradilan. Berkembangnya mediasi lokal di kalangan masyarat Kalisat juga erat kaitannya dengan persepsi yang mereka bangun tentang dunia peradilan. Bagi mereka dunia peradilan hanya alternatif terakhir yang dapat memberikan legalitas atas permohonan ataupun gugatan yang diajukan. Jika dibawa ke dalam kasus perceraian, maka pemahaman demikian berkorelasi dengan keputusan yang menjadi motivasi masyarakat Kalisat mengajukan perkaranya ke hadapan persidangan, yaitu surat perceraian yang dikeluarkan oleh pengadilan sebagai bentuk legalitas atas peristiwa hukum berupa perceraian. Dengan demikian, mediasi yang dijadikan sebagai tahapan penting dalam proses persidangan menjadi sekadar formalitas belaka dan bahkan untuk mempercepat proses persidangan sehingga diperoleh putusan perceraian dan menghindari proses mediasi. Tidak jarang salah satu pihak tidak memenuhi panggilan pengadilan atas dasar kesepakatan bersama bahkan atas saran dari bapak Modin Kalisat. ${ }^{51}$

Tidak kalah pentingnya dari beberapa faktor yang telah dinyatakan di atas adalah faktor yang berupa ketaatan masyarakat Kalisat terhadap seorang kiai. Pilihan hukum masyarakat Kalisat terhadap mediasi lokal sebagai alternatif penyelesaian kasus perceraian yang dihadapinya tidak dapat dipisahkan dari faktor ketaatan mereka

\footnotetext{
49 Ahmad Ali dan Wiwie Heryani, Sosiologi Hukum: Kajian Empiris terhadap Pengadilan (Jakarta: Kencana, 2012), 21.

50 Alfiyah (Penggugat), Wawancara, Kalisat 13 Oktober 2017.

51 Asy'ari (Modin Kalisat), Wawancara, Kalisat 10 Agustus 2017.
} 
terhadap kiai ataupun tokoh masyarakat setempat. Ketaatan mereka terbentuk oleh berbagai dorongan seperti rasa takut kualat jika melanggar perintah kiai maupun dorongan lain yang disebabkan oleh hubungan antara guru murid yang berlaku secara turun-temurun. Hubungan ini dalam konteks kehidupan desa selalu terjaga karena sejumlah murid sekalipun telah lulus dari lembaga pendidikannya masih tetap berhubungan secara baik dengan para kiainya, minimal dalam acara-acara keagamaan tertentu. ${ }^{52}$

Hal demikian disampaikan oleh Adlan. Menurut Adlan, ketaatan masyarakat Kalisat kepada seorang kiai telah mendarah daging, karena memang sejak kecil ia telah berguru kepada kiai kemudian ia mengabdi. Selain itu kata Adlan, setiap guru yang mengajar, dakwahnya kepada para santrinya, jangan wani (berani) ke guru, harus tunduk. Ini menurut Adlan merupakan faktor utama yang menjadikan masyarakat Kalisat tunduk kepada kiai. Karena pelanggaran terhadap apa yang disampaikan kiai, menurut Adlan sering dinilai menimbulkan laknat, sehingga dengan sendirinya tertanam dalam pemahaman masyarakat Kalisat rasa takut kedukah/kualat (laknat) jika tidak tunduk kepada seorang kiai. ${ }^{53}$

Pernyataan Adlan menunjukkan bahwa dalam kehidupan masyarakat desa, termasuk dalam hal ini adalah Kalisat, tokoh masyarakat yang menunjuk kepada orang-orang terkemuka dan kenamaan dalam berbagai bidang kehidupan yang menjadi panutan di masyarakat, ${ }^{54}$ serta kiai yang biasanya dimaknai dengan pemimpin Islam yang dipandang memiliki karisma, baik sebagai pemimpin pesantren atau bukan, karena memang tidak semua kiai memiliki pondok pesantren, tetapi adakalanya hanya sebagai pengajar agama dengan cara berceramah dari desa ke desa untuk memberikan fatwa kepada masyarakat luas, ${ }^{55}$ merupakan tokoh utama yang mampu mengarahkan pola berhukum masyarakat, atau yang disebut oleh Friedman sebagai budaya hukum.

Berbekal kedekatan emosional antara masyarakat Kalisat dengan tokoh masyarakat, timbul rasa kurang meyakinkan jika persoalannya tidak diselesaikan terlebih dahulu oleh tokoh masyarakat setempat.

\footnotetext{
${ }^{52}$ Kuntowijoyo, Budaya dan Masyarakat (Yogyakarta: Tiara Wacana Yogya, 2006), 55.

53 Adlan (Mediator Lokal), Wawancara, Kalisat 11 Oktober 2017.

54 Ahmad Suhendi, "The Role of Local Community Leaders in Social Welfare Development”, Informasi, Vol. 18, No. 2 (2013), 108.

55 Edi Susanto, "Kepemimpinan (Kharismatik) Kyai dalam Perspektif Masyarakat Madura", KARSA, Vol. XI No. 1 (2007), 33.
} 
Seperti disampaikan Mahfud, dalam urusan akad nikah saja, sebelum secara resmi dicatatkan di Kantor Urusan Agama, pasangan calon suami-istri terlebih dahulu meminta untuk diakadkan oleh seorang kiai. ${ }^{56}$

Perasaan demikian itu diungkapkan pula oleh Nurul pada saat menceritakan kasus perceraiannya. Ia menyatakan bahwa ia sebenarnya lebih memilih untuk menyelesaikan kasus perceraiannya kepada seorang kiai karena ia merasa lebih mantap dan saling mengenal walaupun keinginan itu tidak terwujud karena tanpa melalui proses mediasi kepada seorang kiai, perceraiannya langsung diselesaikan di persidangan. ${ }^{57}$

Begitu pula dengan pengakuan Kholisah yang menyatakan:

Iya lebih sreg kepada seorang kiai, karena memang saya ini merasa lebih cocok kepada seorang kiai. Sebelum bercerai secara resmi ke pengadilan ya terlebih dahulu telah bertanya solusinya kepada kiai. Jadi apapun sepertinya memang lebih mantap kepada seorang kiai karena alasan kedekatan emosional). ${ }^{58}$

\section{Mengurai Bekerjanya Faktor non-Hukum di Balik Keberpihak- an Masyarakat Kalisat terhadap Mediasi Lokal}

Kajian hukum sosiologis menempatkan hukum untuk manusia bukan sebaliknya, manusia untuk hukum. ${ }^{59}$ Ini berarti bahwa hukum tidaklah bersifat otonom namun keberlakuannya ditentukan oleh penerimaan manusia yang akan menjadi "konsumen" hukum. Ini dibuktikan dengan ragam kajian tentang relasi hukum dengan faktorfaktor yang dinilai memiliki pengaruh terhadap efektif tidaknya sebuah hukum. Seorjono Soekanto misalnya, menilai penegakan hukum ditentukan oleh lima faktor utama, yaitu faktor hukum itu sendiri, faktor penegakan hukum yang meliputi para pihak yang membentuk dan menerapkan hukum, faktor sarana atau fasilitas yang mendukung penegakan hukum, faktor masyarakat, yakni lingkungan di mana hukum tersebut akan diberlakukan, serta faktor kebudayaan

\footnotetext{
${ }^{56}$ Mahfudz (Mediator Lokal), Wawancara, Kalisat 16 Oktober 2017.

${ }^{57}$ Nurul (Termohon), Wawancara, Kalisat 10 November 2017.

${ }^{58}$ Kholisah (Penggugat), Wawancara, Kalisat 11 November 2017.

59 Satjipto Rahardjo, Hukum Progresif: Sebuah Sintesa Hukum Indonesia (Yogyakarta: Genta Publishing, 2009), 1.
} 
yaitu hasil karya, cipta dan rasa yang didasarkan pada karsa manusia di dalam pergaulan hidupnya. ${ }^{60}$

Kelima faktor di atas, faktor hukum, penegak hukum, sarana, masyarakat serta faktor kebudayaan, menurut Soekanto memiliki arti yang netral sehingga dampak positif atau negatifnya terletak pada isi dari faktor-faktor tersebut, dan memiliki hubungan yang sangat erat antara satu faktor dengan faktor yang lainnya karena ia merupakan esensi dari penegakan hukum yang juga menjadi tolok ukur dari efektifitas penegakan hukum. ${ }^{61}$

Sama halnya dengan teori legal system yang digagas oleh Friedman, yang kemudian membaginya ke dalam tiga unsur yang menjadi esensi dari sebuah sistem hukum, yakni struktur hukum, substansi hukum dan budaya hukum. Struktur hukum berkaitan dengan para hakim, yurisdiksi pengadilan dan lain-lainnya. Sementara substansi hukum berkaitan dengan peraturan dan ketentuan mengenai bagaimana institusi hukum itu harus berperilaku. Sedangkan budaya hukum merupakan kekuatan sosial yang menggerakkan hukum, termasuk ke dalam budaya hukum adalah nilai dan sikap yang dianut oleh para pemimpin dan anggotanya. ${ }^{62}$

Sekian banyak faktor yang menjadi latar belakang timbulnya mediasi lokal di masyarakat Kalisat dapat dikembalikan ke dalam rumusan sistem hukum yang digagas oleh Friedman. Namun demikian, penting ditegaskan bahwa dalam konteks pelacakan terhadap faktor-faktor yang melatari keberpihakan masyarakat Kalisat terhadap mediasi lokal hanya berkisar pada persoalan elemen substansi dan kultur hukum. Dari sisi substansi hukum, mediasi lokal menjadi pilihan hukum masyarakat Kalisat disebabkan oleh tidak adanya sosialisasi hukum seputar mediasi yudisial yang sebenarnya memiliki titik temu dengan budaya masyarakat, yaitu dalam aspek penyelesaian kasus yang didasarkan pada musyawarah mufakat.

Dari sini terlihat bahwa pilihan masyarakat terhadap mediasi lokal tidaklah disebabkan oleh penolakan mereka terhadap substansi yang dikandung oleh ketentuan normatif tentang mediasi yang telah diatur secara positivistik melalui rumusan Peraturan Mahkamah Agung (selanjutnya ditulis PERMA), namun lebih disebabkan oleh

60 Soerjono Soekanto, Faktor-faktor yang Mempengarubi Penegakan Hukum (Jakarta: Rajawali Pers, 2016), 8.

${ }^{61}$ Ibid.

62 Lawrence M. Friedman, Sistem Hukum Perspektif Ilmu Sosial, terj. M. Khozim (Bandung: Nusa Media, 2015), 16. 
ketidaktahuan mereka terhadap ketentuan mediasi yang telah diatur melalui PERMA. Hal ini tentu saja karena memang lahirnya PERMA tentang mediasi bermaksud untuk menguatkan kembali pola berhukum yang telah hidup dalam masyarakat yakni musyawarah mufakat sebagai jalan keluar terhadap kasus yang sedang dialami, atau dengan kata lain, pendekatan yang ditempuh adalah pendekatan kekeluargaan.

Pola-pola berhukum masyarakat yang lebih mengedepankan penyelesaian sengketa secara kekeluargaan telah menjadi hukum yang hidup (living law), sebagaimana dapat ditelusuri dari penggunaan peradilan adat dan peradilan desa sebagai institusi penegak hukum yang mendasarkan pada penyelesaian sengketa melalui pendekatan musyawarah mufakat yang kemudian pada pemerintahan Hindia Belanda juga dibentuk institusi di luar pengadilan yang bertugas untuk menyelesaikan sengketa yang terjadi di kalangan masyarakat tradisional. ${ }^{63}$

Bahkan dengan merujuk kepada Pancasila sebagai dasar filosofis kehidupan masyarakat, terutama pada sila yang berbunyi "kerakyatan yang dipimpin oleh hikmat kebijaksanaan dalam permusyawaratan atau perwakilan", secara tegas mengisyarakatkan pola penyelesaian sengketa yang berdasarkan pada asas musyawarah mufakat. Pemahaman di atas dapat dirujuk dalam Tap. MPR Nomor II/MPR/ 1978 tentang Pedoman Penghayatan dan Pengamalan Pancasila yang menjelaskan bahwa sila keempat sebagaimana telah disebutkan di atas memiliki arti bahwa masyarakat Indonesia memiliki kedudukan, hak dan kewajiban yang sama. Namun dalam melaksanakan semua itu harus disadari perlunya mengutamakan musyawarah dalam mengambil keputusan untuk kepentingan bersama. Musyawarah yang dimaksudkan harus dilandasi oleh semangat kekeluargaan. ${ }^{64}$

Kedudukan musyawarah sebagai pola penyelesaian sengketa dalam kehidupan masyarakat juga memperoleh legitimasi yuridis dengan melihat Pancasila tidak hanya sebagai landasan filosofis bermasyarakat, namun lebih dari itu, pancasila yang telah mengisyaratkan musyawarah mufakat juga menempati posisi grundnorm atau norma dasar. Dalam kedudukannya sebagai norma dasar, pancasila berperan sebagai batu uji validitas tata hukum positif di

${ }^{63}$ Rachmadi Usman, Mediasi di Pengadilan dalam Teori dan Praktek (Jakarta: Sinar Grafika, 2012), 3.

${ }^{64}$ Ibid., 2. 
Indonesia. Artinya, semua norma hukum yang terbentuk harus mendapatkan legalitas dari norma dasar yang dalam hal ini adalah pancasila. ${ }^{65}$

Dengan menempatkan pancasila sebagai norma dasar yang menjadikan musyawarah sebagai salah satu asas hukumnya, maka hukum di Indonesia bukanlah semata-mata perintah otoritas politik sebagaimana dalam aliran legal positivisme, bukan juga sebagai perintah penguasa sebagaimana diajarkan oleh Austin melainkan kristalisasi aspirasi rakyat yang harus diselami dalam jiwa rakyat yang memilikinya, sehingga tugas penting dalam bidang hukum adalah menggali nilai-nilai yang terkandung dalam kehidupan rakyat yang kemudian diwujudkan dalam asas dan doktrin yang sejalan dengan nilai hukum yang dianut oleh masyarakat. ${ }^{66}$

Hal ini semakin memperjelas bahwa PERMA tentang mediasi tentu saja secara substansial harus mengacu pada pancasila sebagai norma dasar dan tentu saja dengan begitu maka PERMA telah mencerminkan penyelesaian sengketa sebagaimana dianut dalam kehidupan masyarakat. Nilai-nilai tersebut tertuang dalam pertimbangan hukum PERMA No. 2 Tahun 2003 yang telah diganti dengan PERMA No. 1 Tahun 2016 tentang Prosedur Mediasi di Pengadilan. Dalam pertimbangan hukumnya, integrasi mediasi ke dalam proses peradilan, di samping untuk mengatasi kemungkinan terjadinya penumpukan perkara juga diarahkan untuk memberikan akses kepada para pihak yang bersengketa untuk memperoleh penyelesaian yang saling memuaskan. Pertimbangan lainnya adalah memaksimalkan fungsi lembaga pengadilan dalam penyelesaian sengketa di samping proses pengadilan yang bersifat memutus (ajudikatif). ${ }^{67}$

65 Bernard L. Tanya, dkk, Pancasila: Bingkai Hukum Indonesia (Yogyakarta: Genta Publishing, 2015), 14.

${ }^{66}$ Ibid., 32. Aspek kultural yang berkembang dalam kehidupan masyarakat tidak dapat "dikorbankan" atas nama modernisasi hukum, karena betapapun modernnya tatanan birokrasi Indonesia, termasuk birokrasi hukum, tidak dapat melepaskan diri dari kungkungan nilai-nilai budaya patrimonial ataupun paternalistik dari budaya masyarakat tradisional yang ditandai dengan kuatnya hubungan kekerabatan, kekeluargaan dan hubungan emosional. Oleh karena itu, sebuah rumusan hukum haruslah mampu menyesuaikan diri dengan perkembangan masyarakat serta tidak menghilangkan aspek kepastian hukumnya. Lihat Agus Suryono, Birokrasi dan Kearifan Lokal (Malang: UB Press, 2017), 50; Wahyudin Husein dan Hufron, Hukum, Politik dan Kepentingan (Yogyakarta: LaksBang, 2008), 22.

${ }^{67}$ Candra Irawan, Aspek. Hukum dan Mekanisme Penyelesaian Sengketa di Luar Pengadilan di Indonesia (Bandung: Mandar Maju, 2010), 22. 
Namun demikian, PERMA secara substansial tentang mediasi telah mencerminkan pola penyelesaian sengketa yang berangkat dari positivisasi nilai-nilai yang berkembang dalam kehidupan masyarakat, dalam praktiknya tidak dapat melepaskan diri dari ketentuanketentuan yang bersifat positivistik, termasuk harus tunduk kepada teori yang umum diberlakukan terhadap setiap ketentuan hukum yang terbentuk dalam konteks hukum positif di Indonesia, yakni teori fiksi yang menyebutkan semua orang dianggap mengetahui sebuah hukum manakala hukum itu telah diundangkan. ${ }^{68}$ Dalam konteks demikian ini, salah satu faktor keberpihakan masyarakat Kalisat terhadap mediasi lokal dapat dipahami, sekalipun tidak dapat dikatakan bahwa "ketidakpedulian" mereka terhadap mediasi yudisial disebabkan oleh pertentangan secara substansial antara pola-pola mediasi lokal dengan ketentuan dalam PERMA yang menjadi dasar keberlakukan mediasi yudisial.

Selain faktor ketidaktahuan tentang ketentuan mediasi yang diakibatkan oleh penerapan teori fiksi, mediasi lokal menjadi alternatif penyelesaian kasus perceraian yang ditempuh oleh masyarakat Kalisat disebabkan oleh rumitnya proses perceraian di Pengadilan Agama sebagaimana disampaikan oleh Durroh ${ }^{69}$ dan Noura. ${ }^{70}$ Merujuk pada pada teori sistem hukum yang digagas oleh Friedman, faktor ini dapat dimasukkan ke dalam unsur substansi hukum, mengingat sebagaimana dimaksudkan oleh Friedman, substansi hukum terdiri dari berbagai peraturan serta ketentuan mengenai bagaimana sebuah institusi itu harus berperilaku. ${ }^{71}$

Jika dikaitkan dengan proses perceraian di Pengadilan Agama, maka tentu saja yang tergolong sebagai substansi hukumnya adalah ketentuan tentang hukum acara serta undang-undang tentang perkawinan yang terhimpun dalam UU 1/1974 dan Kompilasi Hukum Islam. Dalam ketentuan hukum acara, salah satu proses yang harus ditempuh adalah proses mediasi dan berimplikasi pada putusan yang dinilai batal demi hukum manakalah proses tersebut tidak dilaksanakan. ${ }^{72}$ Sementara dalam ketentuan UU 1/1974 dan KHI,

\footnotetext{
${ }^{68}$ Munir Fuady, Dinamika Teori Hukum (Bogor: Ghalia Indonesia, 2010), 12.

${ }^{69}$ Durroh (Penggugat), Wawancara, Kalisat 10 November 2017.

${ }^{70}$ Noura (Penggugat), Wawancara, Kalisat 10 Oktober 2017.

${ }^{71}$ Friedman, Sistem Hukum, 16.

${ }^{72}$ M. Yahya Harahap, Hukum Acara Perdata (Jakarta: Sinar Grafika, 2010), 240.
} 
salah satu di antara sekian banyak ketentuan yang harus diikuti adalah, perceraian harus dilakukan di muka persidangan. ${ }^{73}$

Sebagai gambaran tentang rumitnya proses perceraian sebagaimana diakui oleh informan dalam penelitian ini, berikut akan disajikan proses yang harus ditempuh oleh para pihak yang akan melakukan perceraian di Pengadilan Agama. Secara umum, dengan mengacu pada praktik beracara di Pengadilan Agama, perceraian harus diawali dengan pengajuan permohonan secara lisan ataupun tertulis kepada bagian pendaftaran perkara, di mana permohonan yang dimaksud setidaknya meliputi identitas pemohon dan termohon, posita atau posisi kasus yang harus diuraikan secara singkat, kronologis, jelas dan tepat sehingga mendukung isi tuntutan. Termasuk yang harus ada dalam permohonan adalah petitum, yakni isi tuntutan yang diminta oleh pemohon agar dikabulkan oleh hakim. ${ }^{74}$

Dalam kasus cerai talak, maka seorang suami berkedudukan sebagai pemohon sementara istri sebagai termohon, sehingga dalam hal ini, proses pengajuan permohonannya dilakukan oleh seorang suami. Terhadap permohonan tersebut, sesuai dengan pasal $68 \mathrm{UU}$ No. 7 Tahun 1989 tentang Peradilan Agama yang kemudian dirubah dengan UU No. 3 Tahun 2006 dan UU No. 50 Tahun 2009, hakim Pengadilan Agama harus melakukan pemeriksaan selambat-lambatnya 30 (tiga puluh) hari setelah berkas permohonan cerai talak didaftarkan di kepaniteraan. Jika dihubungkan dengan ketentuan dalam pasal 2 ayat (4) UU No. 48 Tahun 2009, maka jangka waktu 30 (tiga puluh) hari yang diberikan oleh undang-undang kepada majelis hakim untuk memeriksa berkas perceraian yang telah diajukan dapat diperpanjang karena dalam pasal 2 ayat (4) yang diutamakan adalah pemeriksaan yang cermat dalam upaya mewujudkan kebenaran dan keadilan bukan sekadar pemeriksaan yang sesuai dengan jangka waktu yang ditetapkan. ${ }^{75}$

Pada tahapan berikutnya, majelis hakim mulai menyidangkan perkaranya dengan berusaha untuk mendamaikan keduanya. Dalam tahapan ini, suami istri harus datang secara pribadi kecuali jika salah satu pihak berkediaman di luar negeri dan tidak dapat menghadiri sidang dengan agenda mediasi, maka dapat diwakili oleh kuasanya

${ }^{73}$ Lihat pasal 39 ayat (1) UU No. 1/1974 tentang Perkawinan dan pasal 115 dalam KHI.

${ }^{74}$ Gemala Dewi, dkk, Hukum Acara Perdata Peradilan Agama di Indonesia (Jakarta: Kencana, 2006), 120.

${ }^{75}$ Muhammad Syaifuddin, dkk., Hukum Perceraian (Jakarta: Sinar Grafika, 2016), 244. 
yang secara khusus dikuasakan untuk itu. ${ }^{76}$ Tujuan dilakukannya proses mediasi dalam tahapan ini adalah dalam rangka untuk menghentikan persengketaannya dan majelis hakim harus mengupayakan agar perceraian yang diajukan tidak terjadi. Jika proses mediasi ini berhasil, maka permohonan perceraian yang diajukan ke pengadilan dengan sendirinya harus dicabut. ${ }^{77}$ Kemudian hakim mengeluarkan penetapan yang isinya tentang pernyataan pencabutan dan penggugat/pemohon dihukum untuk membayar biaya perkara. ${ }^{78}$

Jika proses mediasi yang ditempuh mengalami kegagalan, maka mediator yang memandu proses tersebut harus membuat surat untuk disampaikan kepada majelis hakim yang memeriksa perkaranya dengan menerangkan bahwa pasangan suami dan istri tersebut gagal mencapai perdamaian sehingga majelis hakim harus melanjutkan proses hukum cerai talak yang dimaksudkan. Atas dasar surat tersebut, maka majelis hakim menganggap kedua belah pihak tidak mungkin lagi didamaikan sehingga menetapkan bahwa perkara tersebut dikabulkan. Terhadap penetapan ini, pihak istri sebagai termohon diberikan hak untuk melakukan banding ke pengadilan tinggi. Setelah penetapan tentang pengabulan perkara memiliki kekuatan hukum tetap, majelis hakim menetukan hari sidang penyaksian ikrar talak dengan memanggil suami sebagai pemohon dan istri sebagai termohon atau kuasanya untuk menghadiri sidang penyaksian ikrar talak tersebut. ${ }^{79}$

Begitu pula dalam kasus gugat cerai di mana istri sebagai penggugat sementara suami sebagai tergugat, harus juga diawali dengan proses pendafataran gugatan sebagaimana dalam kasus cerai talak, dengan memuat permohonan agar Pengadilan Agama memutuskan perkawinan antara penggugat dan tergugat, kemudian berlanjut pada sidang dengan agenda mediasi hingga pada putusan pengadilan tentang putusnya perkawinan karena gugatan perceraian. ${ }^{80}$ Implikasi hukum dari terjadinya perceraian melalui gugat cerai ini, seorang istri tidak mendapatkan hak mut'ah sebab dalam perceraian ini, seorang perempuan tidaklah diceraikan melainkan sebagai penggugat yang melakukan gugatan perceraian untuk seorang suami.

\footnotetext{
76 Ibid., 246.

${ }_{77}$ Manan, Penerapan Hukum Acara Perdata, 174.

78 Ahmad Fathoni Ramli, Administrasi Peradilan Agama (Bandung: Mandar Maju, 2013), 9.

${ }^{79}$ Syaifuddin, Hukum Perceraian, 248.

${ }^{80}$ Ibid., 261.
} 
Selain itu, hak mut'ah tidak berlaku pada dalam kasus putusnya perkawinan yang disebabkan oleh li'än dan faskh, karena dalam kasus li'an, putusnya perkawinan didasarkan pada sumpah masing-masing bukan pada dasar lafal taläq dari suami. Sedangkan dalam kasus faskh, disebabkan oleh tidak sahnya perkawinan yang dilangsungkan sehingga harus dibatalkan. ${ }^{81}$

Demikian gambaran dari apa yang dirasakan oleh informan, bahwa proses perceraian di pengadilan dinilai terlalu rumit. Faktor demikian adalah ketentuan dalam hukum acara yang diterapkan di Pengadilan Agama. Dengan mengacu pada teori yang digagas Friedman, hal ini jelas dapat dikategorikan ke dalam elemen substansi hukum. Rigidnya aturan main peradilan inilah yang menjadi sasaran kritik para pemikir dalam kajian hukum yang berorientasi pada oposisi terhadap positivisme hukum, semisal Satjipto Rahardjo yang dengan tegas menyatakan, ketatnya persoalan yang bersifat birokratis dan prosedural yang dipertontonkan sebagai the rule of the game dalam konstruksi hukum modern berpotensi meminggirkan kebenaran dan keadilan. ${ }^{82}$ Dalam konstruksi demikian dan atas nama kepastian hukum, maka seorang hakim dan tugas yang "dilakonkannya" senantiasa hanya diukur berdasarkan ukuran aturan-aturan yang berlaku termasuk ketentuan hukum acara. ${ }^{83}$

Selain faktor-faktor yang tergolong sebagai elemen substansi hukum, pola berhukum masyarakat Kalisat dengan menjadikan mediasi lokal sebagai pilihan utama dalam penyelesaian kasus perceraian, erat pula kaitannya dengan elemen kultur hukum yang mengacu pada sikap dan nilai sosial. Menurut Friedman, di satu sisi, sikap dan nilai sosial yang dimaksudkan mengacu pada pemahaman publik mengenai pola-pola sikap dan perilaku terhadap sistem hukum. Pada sisi yang lain, juga mengacu pada kultur para profesional hukum yang meliputi nilai-nilai, ideologi dan prinsip para pengacara, hakim dan lainnya yang bekerja dalam lingkaran sistem hukum. ${ }^{84}$ Mengacu pada konsep kultur hukum ini, maka sekian banyak faktor yang penulis identifikasi sebagai latar belakang keberpihakan masyarakat Kalisat dalam menjadikan mediasi lokal dapat dinilai sebagai faktor

81 Indah Purbasari, Hukum Islam sebagai Hukum Positif di Indonesia: Suatu Kajian di Bidang Hukum Keluarga (Malang: Setara Press, 2017), 137.

82 Rahardjo, Hukum Progresif, 12.

83 Ali dan Heryani, Sosiologi Hukum, 2.

${ }^{84}$ Friedman, Sistem Hukum, 255. 
yang berkaitan dengan kultur hukum, baik yang berupa sikap dan pemahaman masyarakat terhadap institusi pengadilan maupun yang berupa penilaian mereka terhadap tokoh masyarakat.

Pemahaman masyarakat Kalisat terhadap ketentuan dalam fiqh sebagai dokumen ajaran agama tentang jatuhnya perceraian serta pandangannya terhadap institusi pengadilan yang dijadikannya sebagai alternatif terakhir dalam perceraian yang ditempuh dalam rangka memperoleh legalitas atas perceraian yang dilakukan merupakan faktor non-hukum yang dapat dimasukkan ke dalam elemen budaya hukum. Implikasi dari pandangan tersebut, proses mediasi yudisial yang menjadi tahap penting dalam persidangan hanya diikuti sebatas formalitas belaka.

Sebagai konsekuensi logis dari pandangan tersebut, maka pengadilan dengan segenap proses dan tahapan hukum acaranya hanya jalan terakhir yang ditempuh ketika terjadi perceraian bukan dalam rangka untuk mempertahankan hubungan perkawinannya melainkan untuk mendapatkan legalitas atas perceraian sebagai fakta hukum yang dilakukannya. Dengan demikian, jika yang dikehendaki adalah perdamaian, dalam arti kembali kepada kehidupan sebagai suami istri, maka pengadilan-dengan salah satu prosesnya adalah mediasi-akan disimpangi, dan mediasi lokallah yang menjadi alternatif penyelesaiannya.

Pernyataan di atas menunjukkan kuatnya pandangan dalam masyarakat tentang citra ajudikatif dalam proses peradilan. Pemahaman ini memang dapat ditelusuri dari fungsi peradilan itu sendiri, yaitu menerima, memeriksa dan mengadili suatu perkara dari sisi kesesuaian dan ketidaksesuaiannya dengan peraturan yang telah ada. ${ }^{85}$ Namun tentu saja pandangan demikian tidak memberikan tempat pada proses mediasi yang diarahkan untuk menunjukkan keseriusan para hakim dalam mengubah citra peradilan sebagai institusi ajudikatif, yang jika dikaitkan dengan kasus perceraian, seorang hakim dibebani kewajiban utama untuk mencegah perceraian dan berupaya untuk mengembalikan keutuhan rumah tangga, bukan hanya sekadar mempertemukan pihak pemohon/penggugat dan

${ }^{85}$ Satjipto Rahardjo, Penegakan Hukum: Suatu Tinjauan Sosiologis (Yogyakarta: Genta Publishing, 2009), 77. 
termohon/tergugat untuk kemudian diputuskan apakah perkara yang diajukan itu ditolak atau dikabulkan. ${ }^{86}$

Untuk menguatkan upaya perdamaian dalam kasus perceraian ini, menurut Abdul Manan, asas mendamaikan sebagai salah satu asas dalam proses peradilan diberlakukan secara imperatif, karena keberhasilan mediasi dalam kasus tersebut dinilai tidak hanya dapat mengembalikan keutuhan rumah tangga namun lebih dari itu dapat menjamin keberlangsungan pemeliharaan anak sebagaimana mestinya. Dalam hal ini, maka seorang hakim dituntut sedapat mungkin untuk dapat menemukan hal-hal yang menjadi latar belakang terjadinya perceraian sehingga dengan demikian akan mudah mencarikan jalan keluar dari persoalan yang sedang dihadapi. ${ }^{87}$

Berdasarkan pada uraian dan fakta hukum di atas, maka nyatalah bahwa pengadilan tidak hanya semata-mata sebagai institusi ajudikatif. Menurut Bagir Manan, penguatan lembaga penyelesaian sengketa alternatif dan revitalisasi fungsi pengadilan untuk mendamaikan para pihak yang bersengketa merupakan salah satu strategi dalam merubah paradigma peradilan dari mengadili ke paradigma menyelesaikan sengketa hukum. Dalam hal perubahan paradigma ini, selain dua hal yang telah disebutkan, strategi lain yang harus dilakukan menurut Bagir Manan adalah menata ulang tata cara penyelesaian perkara menjadi lebih efisien, efektif, produktif dan mencerminkan keterpaduan antar-unsur penegak hukum serta melakukan penataan terhadap hak-hak para pihak yang bersengketa yang menimbulkan konflik permanen dan penyelesaian sengketa yang berlarut-larut. ${ }^{88}$

Kemudian faktor lain yang juga tergolong ke dalam budaya hukum-dalam perspektif Friedman—adalah penilaian masyarakat terhadap tokoh agama dan tokoh masyarakat yang kemudian dijadikan sebagai mediator lokal dalam kasus perceraian adalah faktor yang berupa ketaatan dan kedekatan emosional. Faktor ini dibentuk oleh sekian sebab termasuk karena adanya hubungan guru-murid, adanya rasa sungkan dan khawatir kualat jika tidak patuh kepada seorang kiai. Termasuk juga sebagai penyebabnya adalah keikhlasan para tokoh masyarakat dan kiai dalam memberikan solusi atas kasus perceraian yang sedang dihadapi oleh warganya.

\footnotetext{
${ }^{86}$ Yayah Yarotul Salamah, "Urgensi Mediasi dalam Perkara Perceraian di Pengadilan Agama", Abkam, Vol. XIII, No. 1 (2013), 85.

${ }^{87}$ Manan, Penerapan, 172-3.

${ }^{88}$ Manan, Sistem Peradilan Berwibawa, 25.
} 
Persoalan yang timbul dari proses mediasi lokal yang diakibatkan oleh faktor kedekatan emosional dan ketaatan ini adalah netralitas seorang kiai dan tokoh masyarakat dalam melakukan proses mediasi. Netralitas seorang mediator menjadi hal yang mutlak karena tugas utamanya adalah untuk menggiring para pihak yang terlibat dalam suatu sengketa menuju keputusan yang disepakati bersama. ${ }^{89}$ Sementara dalam praktiknya, mediasi lokal oleh seorang kiai dan tokoh masyarakat sebagaimana terjadi dalam kasus poligami dan kekerasan dalam rumah tangga, tidak memperlihatkan sifat netralitas sebagaimana dikehendaki dalam proses mediasi. Bahkan, yang terlihat adalah dukungan terhadap poligami dengan segala dalil persuasif yang disampaikan, atau pernyataan subordinatif kepada seorang perempuan seperti yang terjadi dalam kasus kekerasan dalam rumah tangga (KDRT).

Beberapa uraian di atas jika dikaitkan dengan tiga elemen yang terdapat dalam teori sistem hukum, yaitu struktur, substansi dan kultur hukum, maka dapat dinyatakan bahwa terjadinya mediasi lokal, hanya berkisar pada penyebab yang dilahirkan dari unsur substansi dan kultur hukum. Struktur hukum termasuk pengadilan dan para hakim/mediator di pengadilan tidak menjadi penyebab keberpihakan masyarakat Kalisat terhadap mediasi lokal. Tentu saja, kesimpulan ini berbeda dengan kajian yang menunjukkan bahwa "kegagalan" mediasi yudisial dilatarbelakangi oleh faktor struktur hukum termasuk di dalamnya adalah mediator.

Analisis ini juga menunjukkan bahwa mediasi lokal seperti yang dipraktikkan dalam kehidupan masyarakat Kalisat, khususnya pada pola mediasi persuasif subordinatif dan persuasif-imajinatif, menjadi instrumen dalam melanggengkan superioritas laki-laki atas perempuan. Sebuah kondisi yang bertentangan dengan fokus pembaharuan yang dikehendaki melalui legislasi hukum keluarga, di mana salah satunya adalah untuk melindungi hak-hak hukum perempuan dari tindakan kesewenang-wenangan laki-laki, seperti hak suami untuk mengucapkan talak sepihak secara mutlak bahkan tanpa alasan yang jelaspun seorang suami boleh menceraikan istrinya. Begitu juga dengan hak mutlak seorang suami untuk berpoligami. Selain dua hal yang telah disebutkan ini, kodifikasi hukum keluarga juga membatasi kebolehan seorang wali (laki-laki) untuk memaksa

89 Peter Lovenheim dan Lisa Guerin, Mediate, Don't Litigate: Strategies for Successful Mediation (USA: Delta Printing Solutions, 2004), 5. 
perempuan yang berada di bawah perwaliannya menikah dengan lakilaki keinginan sang wali bukan sang perempuan. ${ }^{90}$

Pelanggengan superioritas laki-laki atas perempuan seperti yang terjadi di Kalisat ini juga tidak dapat dilepaskan dari budaya manut tokoh masyarakat yang menjadi kepercayaan mereka, sehingga apa yang menjadi pandangan tokoh masyarakat dinilai sebagai kebenaran mutlak dalam agama. Akibatnya, mereka akan cenderung menolak terhadap "suara" lain yang tidak disuarakan oleh tokoh masyarakatnya. Demikian ini yang terlihat secara jelas dalam praktik hukum keluarga utamanya dalam kasus perceraian. Mereka cenderung untuk mengabaikan ketentuan yang termaktub dalam fiqh keluarga mazhab negara, dalam hal ini KHI dan UU No. 1/1974 tentang perkawinan, karena lebih meyakini narasi hukum yang terkodifikasi dalam kitab kuning. 91

Dengan demikian maka ada benarnya bahwa tantangan terhadap reformasi hukum keluarga lebih mengarah pada konteks psikologi sosial kaum muslim, dengan kata lain, adanya pandangan bahwa hukum keluarga adalah hukum Allah yang bersifat final sehingga upaya reformasi terhadapnya dinilai sebagai tindakan yang tidak islami. Kondisi lain yang juga termasuk dalam kategori psikologi sosial kaum muslim adalah keyakinan bahwa hanya ulama sajalah yang berhak untuk menyuarakan kebenaran, sementara upaya reformasi terhadap ketentuan hukum keluarga sering kali tidak disuarakan oleh para ulama. Hal ini menimbulkan keraguan bagi mereka yang konsen terhadap isu pembaruan hukum keluarga untuk membincangnya di ranah publik karena dianggap kontras dengan pandangan ortodoksi. ${ }^{92}$

\section{Penutup}

Persoalan pola berhukum satu komunitas yang dalam hal ini adalah masyarakat Muslim Kalisat dalam menjadikan mediasi lokal

${ }^{90}$ JM. Muslimin, "Hukum Keluarga Islam dalam Potret Interrelasi Sosial", Abkam, Vol. XV, No. 1 (2015), 42.

91 Istilah kitab kuning merujuk pada himpunan kitab yang berisi pelajaran-pelajaran agama Islam mulai dari fiqh, akidah, akhlak dan tasawuf dan lain sebagainya. Kitab ini pula yang menjadi salah satu elemen pesantren, di samping elemen lain seperti pondok, masjid, santri dan kiai. Zamakhsyari Dhofier, Tradisi Pesantren: Studi Pandangan Hidup Kiai dan Visinya Mengenai Masa Depan Indonesia (Jakarta: LP3ES, 2011), 86; Martin Van Bruinessen, Kitab Kuning, Pesantren, dan Tarekat (Yogyakarta: Gading Publishing, 2012), v.

92 Abdul Ghofur dan Sulistiyono, "Eklektisisme dalam Taqnîn Hukum Keluarga di Dunia Islam”, Islamica: Jurnal Studi Keislaman, Vol. 8, No. 2 (2014), 269-270. 
sebagai alternatif utama dalam penyelesaian kasus perceraian yang terjadi di kalangan mereka erat kaitannya dengan faktor-faktor yang bersifat non-hukum. Artinya, keberlakuan hukum-termasuk di dalam hal ini adalah hukum perceraian mazhab pemerintah-secara sosiologis tidaklah bersifat otonom dengan kata lain regulasi hukum tidak berdiri sendiri, melainkan berkelindan di antara ragam faktor non-hukum.

Kenyataan demikian ini yang ditunjukkan oleh pola berhukum masyarakat Kalisat dalam menyelesaikan kasus perceraiannya. Terdapat banyak faktor yang dapat diidentifikasi sebagai faktor yang turut melanggengkan pola berhukum yang dimaksudkan. Sekian faktor tersebut meliputi faktor yang berasal dari pemahaman masyarakat Kalisat terhadap doktrin agama. Selain itu, faktor sosialisasi hukum seputar perceraian yang tidak secara intens dilakukan oleh pemerintah seabagai akibat dari pemberlakukan teori fiksi hukum. Selanjutnya adalah faktor yang berasal dari kesan masyarakat terhadap proses peradilan yang dinilai berbelit-belit dengan banyaknya tahapan dan prosedur yang harus diikuti, dan dalam pandangan masyarakat Kalisat, proses peradilan tidak dapat menyelesaian kasus perceraian secara kekeluargaan sehingga mediasi lokal yang menjadi para kiai sebagai mediatornya dinilai sebagai pola penyelesaian yang lebih mencerminkan sifat kekeluargaan.

Beberapa uraian di atas jika dikaitkan dengan tiga elemen yang terdapat dalam teori sistem hukum, yaitu struktur, substansi dan kultur hukum, maka dapat dinyatakan bahwa terjadinya mediasi lokal hanya berkisar pada penyebab yang dilahirkan dari unsur substansi dan kultur hukum. Struktur hukum termasuk pengadilan dan para hakim/mediator di pengadilan tidak menjadi penyebab keberpihakan masyarakat Kalisat terhadap mediasi lokal. Tentu saja, kesimpulan ini berbeda dengan kajian yang menunjukkan bahwa "kegagalan" mediasi yudisial dilatarbelakangi oleh faktor struktur hukum termasuk di dalamnya adalah mediator.

\section{Daftar Rujukan}

"Masih Perawan Rp. 35 Juta Janda Rp. 15 Juta" dalam https://megapolitan .kompas.com / read/2010/02/20/14444468 /diakses pada tanggal 12 Juni 2016.

Abbas, Syahrizal. Mediasi dalam Hukum Syariah, Hukum Adat dan Hukum Nasional. Jakarta: Kencana, 2011. 
Abdul Qohir (Mediator Lokal), Wawancara, Kalisat 8 November 2017. Adlan (Mediator Lokal). Wawancara. Kalisat 11 Oktober 2017.

Ahmad, Sa'odah binti dan Hak, Nora Abdul. "Family Mediation and Sulh: an Alternative Dispute Resolution in Malaysia", International Journal of Social Policy and Society, Vol. 7, 2010.

Ahmad, Sa'odah Binti. "Sulb: an Alternative Dispute Resolution and Amicable Settlement of Family Dispute", UMRAN: Journal of Muslim Affairs, Vol. 1, No. 1, 2015.

Ahrons, Constance. The Good Divorce: Keeping Your Family Together When Your Marriage Comes Apart. t.t.: International and Pan-American, 2008.

Alfiyah (Penggugat). Wawancara. Kalisat 13 Oktober 2017.

Ali, Achmad dan Heryani, Wiwie. Sosiologi Hukum: Kajian Empiris terbadap Pengadilan. Jakarta: Kencana, 2012.

Ali, Achmad. Menguak Teori Hukum dan Teori Peradilan, Vol. 1. Jakarta: Kencana, 2013.

Asy'ari (Modin Kalisat). Wawancara. Kalisat 10 Agustus 2017.

Bruinessen, Martin Van. Kitab Kuning, Pesantren, dan Tarekat. Yogyakarta: Gading Publishing, 2012.

Cotterrel, Roger. Sosiologi Hukum, terj. Narulita Yusron. Bandung: Nusa Media, 2016.

Dewi, Gemala dkk. Hukum Acara Perdata Peradilan Agama di Indonesia. Jakarta: Kencana, 2006.

Dhofier, Zamakhsyari. Tradisi Pesantren: Studi Pandangan Hidup Kiai dan Visinya Mengenai Masa Depan Indonesia. Jakarta: LP3ES, 2011.

Durroh (Penggugat). Wawancara. Kalisat 10 November 2017.

Fitriany, Aulia dan Fajriyah, Izzatul. "Sejarah Budaya Kawin Sirri di

Desa Kalisat Kecamatan Rembang Kabupaten Pasuruan", Jurnal Edukasi, Vol. 1 No. 2, 2015.

Friedman, Lawrence M. American Law in the 20th Century. United States of America: R. R. Donnelley \& Sons, 2002.

Friedman, Lawrence M. Sistem Hukum Perspektif Ilmu Sosial, terj. M. Khozim. Bandung: Nusa Media, 2015.

Fuady, Munir. Dinamika Teori Hukum. Bogor: Ghalia Indonesia, 2010.

Ghofur, Abdul dan Sulistiyono. "Eklektisisme dalam Taqnîn Hukum Keluarga di Dunia Islam", Islamica: Jurnal Studi Keislaman, Vol. 8, No. 2, 2014.

Harahap, M. Yahya. Hukum Acara Perdata. Jakarta: Sinar Grafika, 2010. 
Hidayat, Maskur. Strategi dan Taktik Mediasi Berdasarkan PERMA No. 1 Tahun 2016 Tentang Prosedur Mediasi di Pengadilan. Jakarta: Kencana, 2016.

Husein (Mediator Lokal). Wawancara. Kalisat 10 Agustus 2017.

Husein, Wahyudin dan Hufron. Hukum, Politik dan Kepentingan. Yogyakarta: LaksBang, 2008.

Indah Purbasari, Hukum Islam sebagai Hukum Positif di Indonesia: Suatu Kajian di Bidang Hukum Keluarga. Malang: Setara Press, 2017.

Irawan, Candra. Aspek. Hukum dan Mekanisme Penyelesaian Sengketa di

Luar Pengadilan di Indonesia. Bandung: Mandar Maju, 2010.

Ismail (Mediator Lokal). Wawancara. Kalisat 16 September 2017.

Juwaynī (al), 'Abd al-Mālik b. 'Abd Allāh b. Yūsuf. Nihāyat al-Matlab fì

Dirāyat al-Madhhab, Vol. 14. Jeddah: Dār al-Minhāj, 2007.

Kholisah (Penggugat). Wawancara. Kalisat 11 November 2017.

Kodiran. "Kebudayaan Jawa", dalam, Koentjaraningrat, Manusia dan Kebudayaan di Indonesia. t.t.: Penerbit Djambatan, 1980.

Kosim, Mohammad. "Kiai dan Blater (Elite Lokal dalam Masyarakat Madura), KARSA, Vol. XII No. 2, 2007.

Kuntowijoyo. Budaya dan Masyarakat. Yogyakarta: Tiara Wacana Yogya, 2006.

Kuntowijoyo. Perubahan Sosial dalam Masyarakat Agraris Madura 18501940. Yogyakarta: Mata Bangsa, 2002.

Lovenheim, Peter dan Guerin, Lisa. Mediate, Don't Litigate: Strategies for Successful Mediation. USA: Delta Printing Solutions, 2004.

Magnis-Suseno, Franz. Etika Jawa: Sebuah Analisa Falsafi tentang Kebijaksanaan Hidup Jawa. Jakarta: PT. Gramedia, 1985.

Mahfudz (Mediator Lokal). Wawancara. Kalisat 16 Oktober 2017.

Manan, Abdul. Penerapan Hukum Acara Perdata di Lingkungan Peradilan Agama. Jakarta: Kencana, 2016.

Manan, Bagir. Sistem Peradilan Berwibawa. Yogyakarta: UII Press, 2005.

Muslimin, JM. "Hukum Keluarga Islam dalam Potret Interrelasi Sosial", Abkam, Vol. XV, No. 1, 2015.

Noura (Penggugat). Wawancara. Kalisat 10 Oktober 2017.

Nurul (Termohon). Wawancara. Kalisat 10 November 2017.

Qohir, Abdul (Media Lokal). Wawancara. Kalisat 8 November 2017.

Rahardjo, Satjipto. Hukum Progresif: Sebuah Sintesa Hukum Indonesia.

Yogyakarta: Genta Publishing, 2009.

Rahardjo, Satjipto. Pemanfaatan Ilmu-ilmu Sosial bagi Pengembangan Ilmu

Hukum. Yogyakarta: Genta Publishing, 2010. 
Rahardjo, Satjipto. Penegakan Hukum: Suatu Tinjauan Sosiologis. Yogyakarta: Genta Publishing, 2009.

Ramli, Ahmad Fathoni. Administrasi Peradilan Agama. Bandung: Mandar Maju, 2013.

Rato, Dominikus. Dunia Hukum Orang Osing. Yogyakarta: LaksBang Mediatama, 2009.

Rato, Dominikus. Hukum dalam Perspektif Konstruksi Sosial. Yogyakarta: LaksBang Mediatama, 2009.

Sabiq, Sayyid. Fiqh al-Sunnah, Vol. 2. Kairo: Dār al-Fatḥ li al-I'lām al'Arabī, 1995.

Salamah, Yayah Yarotul. "Urgensi Mediasi dalam Perkara Perceraian di Pengadilan Agama", Ahkam, Vol. XIII, No. 1, 2013.

Silbey, Susan S. "Legal Culture and Cultures of Legality", dalam, John R. Hall, Laura Grindstaff and Ming Cheng Lo (eds.), Handbook of Cultural Sociology. New York: Routledge, 2010.

Sodiqin, Ali. "Antropologi Hukum sebagai Pendekatan dalam Penelitian Hukum Islam", al-Manāhij: Jurnal Kajian Hukum Islam, Vol. 7, No. 1, 2013.

Soekanto, Soerjono. Faktor-faktor yang Mempengarubi Penegakan Hukum. Jakarta: Rajawali Pers, 2016.

Soesilo, R. RIB/HIR dengan Penjelasan. Bogor: Politeia, 1985.

Suhendi, Ahmad. "The Role of Local Community Leaders in Social Welfare Development”, Informasi, Vol. 18, No. 2, 2013.

Suryono, Agus. Birokrasi dan Kearifan Lokal. Malang: UB Press, 2017.

Susanto, Edi. "Kepemimpinan (Kharismatik) Kyai dalam Perspektif Masyarakat Madura", KARSA, Vol. XI No. 1, 2007.

Sutantio, Retnowulan. Mediasi dan Dading dalam Mediasi dan Perdamaian. Bandung: Alumni, t.th.

Syaifuddin, Muhammad dkk., Hukum Perceraian. Jakarta: Sinar Grafika, 2016.

Tanya, Bernard L. dkk. Pancasila: Bingkai Hukum Indonesia. Yogyakarta: Genta Publishing, 2015.

Tanya, Bernard L. Hukum dalam Ruang Sosial. Yogyakarta: Genta Publishing, 2010.

Usman, Rachmadi. Mediasi di Pengadilan dalam Teori dan Praktek. Jakarta: Sinar Grafika, 2012.

Wensick, A. J. al-Mujam al-Mufahras li Alfäz̆ al-Hadith al-Nabawì, Vol. 4. Leiden: Maktabah Brill, 1926. 
Wulansari, Dewi. Sosiologi Konsep dan Teori. Bandung: Refika Aditama, 2009.

Zuhaylī (al), Wahbah. al-Tafsir al-Munir fi al-'Aqidah wa al-Sharīab wa alMinhaj, Vol. 3. Damaskus: Dār al-Fikr, 2009. 